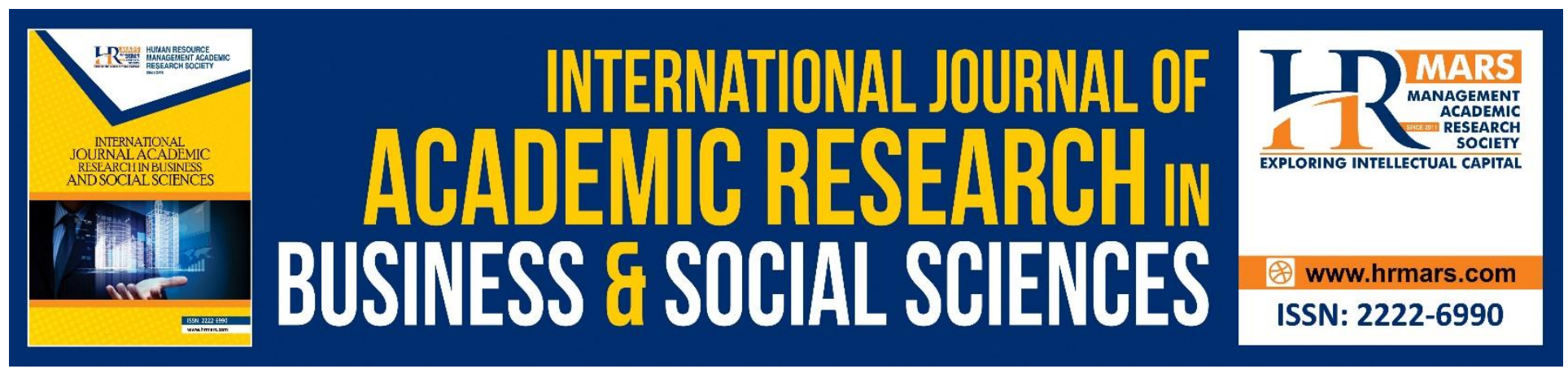

\title{
Are Malaysian Public Universities Inclusive Enough? A Study on The Needs of Students with Disabilities
}

Roslinda Alias, Nor Aziah Alias, Johan Eddy Luaran, Rosilawati Sueb, and Mahadi Kamaludin

To Link this Article: http://dx.doi.org/10.6007/IJARBSS/v10-i14/7681

DOI:10.6007/IJARBSS/v10-i14/7681

Received: 03 April 2020, Revised: 09 May 2020, Accepted: 17 June 2020

Published Online: 26 June 2020

In-Text Citation: (Alias et al., 2020)

To Cite this Article: Alias, R., Alias, N. A., Luaran, J. E., Sueb, R., \& Kamaludin, M. (2020). Are Malaysian Public Universities Inclusive Enough? A Study on The Needs of Students with Disabilities. International Journal of Academic Research in Business and Social Sciences, 10(14), 114-122.

Copyright: (C) 2020 The Author(s)

Published by Human Resource Management Academic Research Society (www.hrmars.com)

This article is published under the Creative Commons Attribution (CC BY 4.0) license. Anyone may reproduce, distribute, translate and create derivative works of this article (for both commercial and non-commercial purposes), subject to full attribution to the original publication and authors. The full terms of this license may be seen at: http://creativecommons.org/licences/by/4.0/legalcode

Special Issue: WSTI2018 - Issues and Trends on Education, Science and Technology, 2020, Pg. 114 - 122 http://hrmars.com/index.php/pages/detail/IJARBSS

Full Terms \& Conditions of access and use can be found at http://hrmars.com/index.php/pages/detail/publication-ethics 


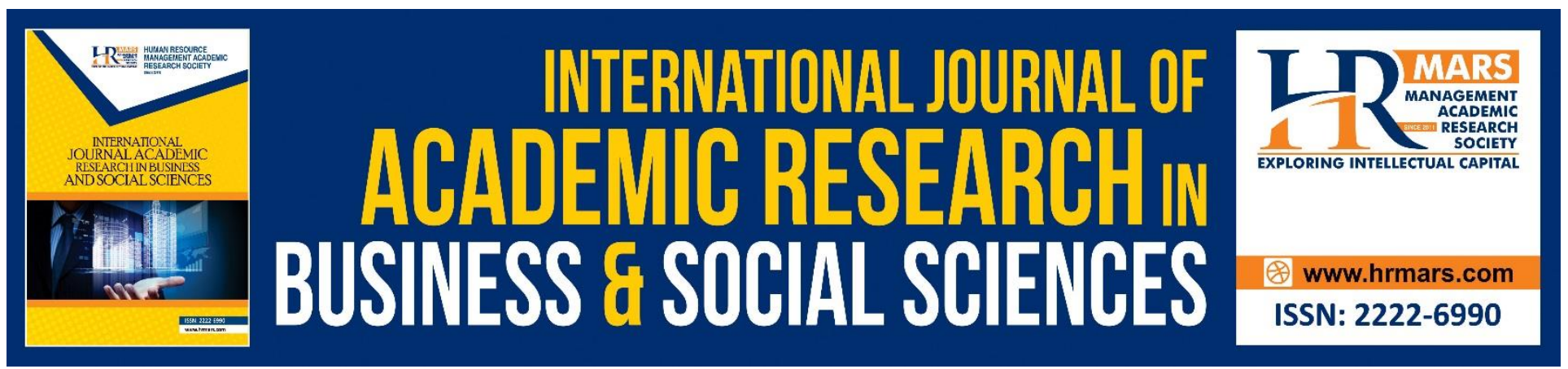

\title{
Are Malaysian Public Universities Inclusive Enough? A Study on The Needs of Students with Disabilities
}

\author{
Roslinda Alias ${ }^{1}$, Nor Aziah Alias², Johan Eddy Luaran³, Rosilawati \\ $\mathrm{Sueb}^{4}$, and Mahadi Kamaludin ${ }^{5}$ \\ Universiti Teknologi MARA, 42300 Puncak Alam, Selangor, Malaysia \\ Email: ${ }^{1}$ linda512@salam.uitm.edu.my, ${ }^{2}$ noraz112@salam.uitm.edu.my, \\ 3johaneddyluaran@gmail.com, ${ }^{4}$ rosilasueb@gmail.com, ${ }^{5}$ mahadi2727@salam.uitm.edu.my
}

\begin{abstract}
This paper discusses the needs of students with disabilities (SWDs) at a local public university. Twenty-one SWDs aged between 19 and 24 years old, across 15 faculties voluntarily involved themselves in this study. The study showed that the provision of disabled-friendly facilities at the university is still severely lacking and improvement must be made so that this will facilitate the teaching and learning process particularly for SWDs. Support services such as special counselling services and special programmes for SWDs should be enhanced as suggested by the participants of this study. In addition, awareness towards SWDs should also be inculcated among university staff and students so that an inclusive environment can be established in the university to support SWDs.
\end{abstract}

Keywords: Students with Disabilities (SWDs), Persons with Disabilities (PWDs), Inclusive Education, Higher Education, Needs of the Disabled, Education.

\section{Introduction}

Mahathir bin Mohammad introduced the ultimate vision of Malaysia i.e. the Vision 2020 in the year 1991. The vision aims by the year 2020 to make Malaysia a fully developed country in all aspects.

Earlier in January 2017, the former Prime Minister of Malaysia Najib Tun Abdul Razak launched Transformasi Nasional 2050 (TN50) gearing Malaysia to be among the top countries in the world "in economic development, citizen well-being and innovation" by 2050 (Ministry of Youth and Sport, 2017).

Education is among the main focus in order to achieve both Vision 2020 and TN50. The important role of education in Malaysia could be seen through the agenda presented in the Malaysia Plans, from the First Malaysia Plan 1966-1970 to the Eleventh Malaysia Plan 2016-2020.

In Malaysia, persons with disabilities (PWDs) have equal opportunity to receive education from pre-school to higher education as stated in the Persons with Disabilities Act 2008 and Action Plan for Persons with Disabilities by the Ministry of Women Family and Community. 
It is a must for every educational institution (from pre-school up to tertiary education) to create an inclusive environment for all without practising discrimination based on their personal background, race, ability and gender so that none is left out in their pursuit of education. The provision of an inclusive learning environment will foster effective learning processes in educational institutions.

Inclusive education refers to providing equal opportunity in education to all students "regardless of their physical, intellectual, social, emotional, linguistic or other conditions" (UNESCO, 1994, p.6). According to Corbett (2000), inclusive education "is about fostering a learning community which treats individuals with dignity and respect and it is about celebrating difference" (p.73).

Malaysia embraces this inclusive education movement. The continuous efforts towards this movement can be seen in the Malaysian Education Blueprint 2013-2025 (Ministry of Education, 2012), that emphasizes equity of education for all Malaysians including students with disabilities (SWDs).

However, there is a need for greater involvement in this endeavour as findings from studies in Malaysia point out that SWDs particularly in higher education face multiple challenges and barriers in education and some of their needs could be catered to by their respective learning institutions (Alias et al., 2017; Alias, 2016; Osman et al., 2015; Salleh \& Mahani, 2010; Toran et al., 2009). If left unattended to, this could impede the establishment of inclusive environment in universities.

The main purpose of the present study is to examine the needs of SWDs in teaching and learning in a particular university in Malaysia. By acknowledging the needs of SWDs, proactive measures can be taken particularly in ensuring that there is provision of a special support system so that an inclusive environment materializes.

\section{Literature Review}

Inclusive education in universities: Welcoming and involving students with disabilities (SWDs) in the campus

Inclusive environment in universities is when everybody receives equal opportunity in the teaching and learning processes. As explained by Topping and Maloney (2005), equal opportunity does not refer to giving equal treatment to everyone rather it denotes "treating people differently" according to their needs and ability so that it elevates abilities and potentials.

Fernie and Henning (2006) proposed that to ensure inclusive environment could be materializes in the university, SWDs should be aware of and be familiar with services offered by the university so that they will benefit from them. Besides that, they should also develop good study habits so that they can adopt to the new learning environment. The role of lecturers is also emphasized in which their support on the inclusive education agenda is really needed.

In addition, the role of technology cannot be denied in creating an inclusive environment as technology is a vital support for SWDs to thrive in their learning environment (Alias et al., 2017; Kamaruzaman et al., 2016; Gavira et al., 2016; Ibrahim et al. , 2016; Alias et al., 2013; Milsom et al., 2006; Kyun et al., 2007).

Alias et al. (2013) suggested the use of tablets, the improvisation of the existing learning management system (LMS) and the utilization of Web 2.0 in teaching and learning to create an inclusive atmosphere in higher education particularly for SWDs.

In Ibrahim et al. (2016) study on the deaf students and teachers in Special Education Secondary Vocational School (SESVS), both teachers and SWDs agreed that technology is a must to 
enhance teaching and learning and to promote an inclusive environment in the school. This is because technology enabled SWDs to communicate effortlessly with their non-disabled peers.

The provision of physical support, intellectual support as well as social emotional support are equally important to foster effective teaching and learning processes for SWDs at the universities (Alias, 2016).

Various studies have been carried out on issues related to physical support in learning. For instance, in United States, Wernsman (2008) focused on the process of designing and creating accessible residence hall for SWDs at one university.

Salleh and Mahani (2010) and Hanafi et al. (2010) emphasized on the importance of physical supports and a SWD-friendly atmosphere in promoting the learning processes at all levels of education.

Ta (2011) identified two main challenges encountered by SWDs in Malaysia in pursuing education which are 1) non-conducive buildings and surroundings and 2) poor access to public transportation. Zahari et al. (2016), reiterated the same issues as barriers for the disabled tourists to visit heritage buildings in Malaysia.

Arifin and Mahmud (2010) identified that the accessibility for SWDs of the five Malaysian universities did not achieve satisfactory level. Besides that, adequate provision for others special facilities such as SWD-friendly toilets and parking bays around the campus areas were also overlooked by Malaysian universities.

Similarly Alias, (2016), Osman et al., (2015), Salleh and Mahani (2010) and Rosman et al. (2009) also found Malaysian universities unequal in their provision of facilities on campus grounds.

For intellectual support, Fernie and Henning, (2006) and Hall and Stahl (2006) proposed educators use a variety of teaching methods to encourage the engagement of all students including SWDs in the learning process. The provision of flexible assessments will support the SWDs intellectually in universities as highlighted by Fernie and Henning (2006) and Waterfield, West and Parker (2006).

For social and emotional support Mohammad and Suhaili (2011) highlighted the importance of parental and community involvement to support the education of SWDs. Meanwhile, to inculcate positive awareness among non-SWDs towards SWDs at the university Alias et al. (2016) suggested the utilization of service learning method in teaching processes. Service learning is a branch of experiential learning which it focuses on the balance of community services and formal education (Furco, 1996).

In Alias et al. (2016) study, thirty-three non-SWDs from one public university were involved as facilitators for a 3-day program involving the PWDs. The organization of this program was part of the learning outcomes and evaluated at the end of the semester. Based on the reflection reports submitted, it proved that the implementation of service learning method enhancing the non-SWDs positive attitudes and perceptions towards PWDs.

Based on literature, it is important to understand the needs of SWDs so that inclusive environment can be established and education for all can be materialize.

\section{Methodology}

The present study utilized a cross-sectional survey research methodology. The target population of the study were SWDs studying in Universiti Teknologi MARA (UiTM) Malaysia. The 
Education Planning and Research Division (EPRD), Ministry of Education reported, from the year 2008 to 2010 , there were 486 registered SWDs who enrolled at UiTM.

The purposive sampling method was employed in the selection of the participants. Only participants who signed the inform consent form provided with the questionnaire were included in the study.

Questionnaires consisting of demographic background questions, challenges and barriers and seven open-ended questions were distributed. The open-ended questions focused on the needs of SWDs across seven elements which are university facilities, support services, academic and administrative staff, non-SWD friends, special facilities for SWDs, technology for teaching and learning and other needs.

\section{Results and Discussion}

\section{Demographic background}

Twenty-one SWDs took part in the study in which 10 of them are males. The age range of the SWDs for this study is between 19 years old and 28 years old. Table 1 shows the summary on age and genders of participants of the present study.

Table 1: Summary on age and genders of participants of the study

\begin{tabular}{lcccccc}
\hline & \multicolumn{5}{c}{ Age } \\
\hline \multirow{2}{*}{ Gender Male } & $19-20$ & $21-22$ & $23-24$ & $25-26$ & $27-28$ \\
& \multirow{2}{*}{ Female } & 7 & 3 & 2 & 0 & 1 \\
& & 11 & 3 & 5 & 1 & 0 \\
\hline Total & & & 0 & 3 & 1 \\
\hline
\end{tabular}

Eleven of the participants are currently pursuing their degrees while 10 of them are enrolled in diploma courses across 13 specializations including accountancy, architecture, business, chemistry, film, food technology sciences, information management, office management and technology, mathematics, mechanical engineering, physics, physiotherapy and sport sciences.

As shown in Table 2, a majority of the SWDs are partially sighted (six of them), two are blind on one eye, three are hearing impaired, two are wheelchair bound and the rest have varied disabilities.

\section{University Facilities Required by Students with Disabilities (SWDs)}

Three of the participants urged that university facilities be improved to cater for their needs in teaching and learning. And four who are partially sighted or hearing impaired or slow learner or with multiple disabilities stated that facilities should be accessible and barrier-free for SWDs. For wheelchair users and SWDs with mobility difficulty, they suggested that the university should provide suitable locations for classroom and hostel, preferably on ground floor.

There were also requests from SWDs to have more special facilities at the hostel such as handle bars and ramps. SWDs also requested the provision of more special facilities in university including privileged parking lots, special toilets, special wheelchair route and special lifts. One of the SWDs responded that the university paid less attention in providing special facilities for SWDs. 
The lack of disabled-friendly facilities does not only exist at the university in the current study. The provision disabled-friendly facilites are limited as reported by SWDs in other universities in Malaysia (Alias, 2016; Osman et al., 2015; Salleh \& Mahani, 2010; Rosman et al., 2009).

\section{University Support Services and Students with Disabilities (SWDs)}

One of SWDs suggested the university provide a good support system by stating, "Berikan tugasan yang berbeza seiring dengan fizikal indvidu [provide different tasks according to the ability of each individual].

There was a suggestion from two SWDs for the provision of special counselling services for them. Five respondents urged for the inclusion of special advocacy programmes for SWDs in the university so that they are aware of their rights as students of higher education.

In addition, two of the respondents reported that they were not aware of any support services provided for them and requested that the information be well disseminated. As highlighted by Alias (2016) support which includes physical support, intellectual support as well as social emotional support are vital to help the SWDs to adapt to university environment.

\section{University Staff and Students with Disabilities (SWDs)}

Four SWDs claimed that there is a lack of awareness on the disabled issues especially among lecturers. For example, lecturers did not know how to cater for the needs of SWDs in teaching and learning. The university staff should be more helpful and supportive for SWDs as proposed by the respondents of the study. Besides, they should be treated and respected equally like other students.

The staff should be friendlier towards the SWDs as urged by one of the SWDs "Staf harus lebih positif dan mesra dengan pelajar OKU. Kamipun manusia, right?" [Staff should be more positive and friendly towards SWDs. We are also humans, aren't we?]

\section{Relationship with non-SWD Friends}

Similar to the findings with regards to university staff, SWDs also stated that some of their non-SWD friends were not aware of the issues faced by the PWDs. Hence, several non-SWD friends did not know of the challenges and barriers faced by them. As a result, the participants of the study wished that their non-SWD friends were more helpful, supportive and friendly.

However, nine (9) SWDs reported they have fostered good relations with their non-SWD friends and one of the participants explained that "I am okay with them, mungkin sebab kelainan saya tidak terlalu menonjol" [I am okay with them (non-SWD friends), as my disability is not obvious].

\section{Meeting the Needs for Basic Facilities among Students with Disabilities (SWDs)}

When the question on the basic special facilities required for them, SWDs listed these facilities:

- Ramp

- Special Parking

- Special lift with handle bar

- Special Braille Path

- Hearing aids

- Special toilets

- Wheelchair path 
The above facilities are common and basic facilities for PWDs, not only in the university but also in other public places as highlighted by Ta (2011) and Zahari et al. (2016).

\section{Technology in Teaching and Learning for Students with Disabilities (SWDs)}

SWDs were also asked to propose suitable technology that could aid them in the teaching and learning process. Below are the responses:

- Embosser and Braille paper for the partially sighted and blind students

- Special software - for the deaf, blind or partially sighted

- Braille note/books/references for the partially sighted and blind students

- Screen reader for the blind or partially sighted

- Extra courses for the deaf and blind students

- Good audio system in lecture halls for the partially sighted, blind and hearing-impaired students

\section{Conclusion}

Malaysian universities should improve their existing SWDs supports and facilities so that a SWD-friendly environment materializes. Based on the feedback from the SWDs, there is a great need to ensure that disabled-friendly facilities are provided at the university.

Despite the small number of SWDs compared to mainstream learners, their inclusion into the learning environment particularly in higher education is critical.

\section{Acknowledgement}

Special thanks to Universiti Teknologi MARA on the support to conduct this study under research grant ARAS - 600-IRMI/DANA 5/3/ARAS (0075/2016).

\section{References}

Arifin, R., \& Mahmud, Z. (2010). Facilities and Accessibility for the Disabled at Institutions of Higher Learning in Malaysia. Malaysian Journal of Sport Science and Recreation, 6(2), 13-24.

Alias, R. (2016). Development and Validation of A Model of Technology Supported Learning for Special Educational Needs Learners in Malaysian Institutions of Higher Learning. Universiti Teknologi MARA.

Alias, R., Alias, N. A., Ibrahim, A. B., \& Jalaluddin, J. (2013). Proposed Technology Solutions for Special Educational Needs ( SEN ) Learners: Towards Inclusive Education in Malaysian Universities. International Journal of Information and Education Technology, 3(2), 206-210.

Alias, R., Alias, N. A., Luaran, J. E., Noor, H. M., \& Rahenan, N. F. (2016). Service Learning for Inclusive Society in Malaysia. In Student-Driven Learning Strategies for the 21st Century Classroom (pp. 169-178). IGI-Global. https://doi.org/10.4018/978-1-5225-1689-7.ch012.

Alias, R., Alias, N. A., Luaran, J. E., Sueb, R., \& Kamaludin, M. (2017). The Model of TechnologySupported Learning for Special Educational Needs Learners: Towards Inclusive Environment for Students With Disabilities (SWDs) in Malaysian Higher Education. In H. C. Alphin, R. Y. Chan, \& J. Lavine (Eds.), The Future of Accessibility in International Higher Education (pp. 202218). IGI-Global. https://doi.org/10.4018/978-1-5225-2560-8.ch012. 
Corbett, J. (2000). Journeys in Inclusive Education: Profiles and Reflections. In P. Clough \& J. Corbett (Eds.), Theories of Inclusive Education (1st Edn, pp. 70-73). London: Paul Chapman Publishing Ltd.

Fernie, T., \& Henning, M. (2006). From a Disabling World to a New Vision. In M. Adams \& S. Brown (Eds.), Towards Inclusive Learning in Higher Education: Developing Curricula for Disabled (1st Editio, pp. 23-31). New York: Routledge.

Furco, A. (1996). Service -Learning: A Balanced Appoach to Experiential Education. Expanding Boundaries: Serving and Learning, 2-6.

Hall, T., \& Stahl, S. (2006). Using Universal Design for Learning to Expand Access of Higher Education. In M. Adams \& S. Brown (Eds.), Towards Inclusive Learning in Higher Education: Developing Curricula for Disabled (1st Editio, pp. 67-78). New York: Routledge.

Toran, H., Hanafi, M., Mokhtar, M., \& Sujak, N. (2009). Sokongan dan Halangan yang dihadapi PelajarPelajar Kurang Upaya di Sebuah Institusi Pengajian Tinggi di Malaysia. Asean Journal of Teaching and Learning in Higher Education, 1(2), 18-29. Retrieved from http://journalarticle.ukm.my/1486/

Kamaruzaman, M. F. ., Nor, H. M., \& Azahari, M. H. H. (2016). Using touchscreen technology to support basic numeracy learning process for high functioning children with autism. Turkish Online Journal of Educational Technology, 2016(July), 632-639. Retrieved from https://www.scopus.com/inward/record.uri?eid=2-s2.0-

84985993492\&partnerID=40\&md5=a87599d7990a7efaa10f960370dcc4bf

Kyun, N. C., Tat, L. Y., Saripan, M. I., \& Abbas, A. F. (2007). Education for All: Disabled Friendly Flexi ELearning System. In AEESEAP Regional Symposium on Engineering Education (pp. 120-124). Serdang: Universiti Putra Malaysia.

Lopez-Gavira, R., Moriña, A., Melero-Aguilar, N., \& Perera-Rodríguez, V. H. (2016). Proposals for the Improvement of University Classrooms: The Perspective of Students with Disabilities. Procedia - Social and Behavioral Sciences, 228(June), 175-182.

https://doi.org/10.1016/j.sbspro.2016.07.026

Osman, M. M., Radzi, F. H. M., Bakri, N. I. M., \& Ibrahim, M. (2015). Barrier-free Campus: University Malaya, Kuala Lumpur. Procedia - Social and Behavioral Sciences, 168, 134-144. https://doi.org/10.1016/j.sbspro.2014.10.219

Milsom, C., Anwar, N., \& Thompson, S. (2006). Developing an Inclusive Curriculum for Students with Mobility Impairments. (M. Hills \& M. Healey, Eds.). Gloucestershire: Geography Discipline Network.

Ministry of Education. (2012). Malaysia Education Blueprint 2013 - 2025. Putrajaya.

Ministry of Women Family and Community. (2016). Action Plan for Persons with Disabilities 20162022. Putrajaya: Ministry of Women Family and Community. Retrieved from https://www.kpwkm.gov.my/kpwkm/uploads/files/Dokumen/Dasar/PelanTindakan_OKU.pd $f$

Ministry of Youth and Sport. (2017). Transformasi Nasional 2050 (TN50). Retrieved February 22, 2017, from https://mytn50.com/?language=eng

Hanafi, M., Toran, H., Mokhtar, M., \& Bari, S. (2010). Special Education Classroom Infrastructure : Teacher ' S Views. Procedia Social and Behavioral Sciences, 7(C), 601-604. https://doi.org/10.1016/j.sbspro.2010.10.081. 
Ibrahim, Z., Alias N., \& Nordin, A. B. (2016). Needs analysis for graphic design learning module based on technology \&amp; learning styles of deaf students. Cogent Education, 3(1). https://doi.org/10.1080/2331186X.2016.1178364

Rosman, M., Hanafi, M., \& Mokhtar, M. (2009). Pembinaan Sistem Sokongan untuk Pelajar Berkeperluan Khas Bermasalah Pembelajaran: Satu Kajian Kes di Sebuah Sekolah Menengah di Negeri Johor. In Zamri Mahamod, Safani Bari, Rosadah Abdul Majid, \& Hamidah Yamat (Eds.), Proceedings of the Regional Conference on Inclusion and Special Educational Needs (pp. 111-125). Bangi: Faculty of Education UKM.

Salleh, N. M., \& Mahani, D. H. (2010). Sistem Sokongan untuk Pelajar Bermasalah Penglihatan di Institusi Pengajian Tinggi. In Zamri Mahamod, Safani Bari, Rosadah Abdul Majid, \& Hamidah Yamat (Eds.), Proceedings of the Regional Conference on Inclusion and Special Educational Needs (pp. 158-163). Bangi: Faculty of Education UKM.

Law of Malaysia. (2018). Person With Disabilities Act 2008. In The Commissioner of Law Revision, Malaysia Under the Authority of the Revision of Laws Act 1968. https://doi.org/10.4324/9780203795422.

Mohammad, R., \& Suhaili, S. M. (2011). Presentation of The Involvement of the Community in Inclusive Education. Brunei Darul Salam: The ASEAN Cooperative Conference on Inclusive Education, 2011.

Ta, T. L. (2011, June). Poor Facilities Denying Disabled the Right to Further Education. Sunday Star, p. 16.

Topping, K., \& Maloney, S. (2005). Introduction. In K. Topping \& S. Maloney (Eds.), The RoutledgeFalmer Reader in Inclusive Education (1st Edn, pp. 1-14). New York: Routledge Falmer Taylor \& Francis Group.

UNESCO. (1994). The Salamanca Statement and Framework for Action on Special Need Education. France: UNESCO. Retrieved from http://www.unesco.org/education/pdf/SALAMA_E.PDF

Waterfield, J., West, B., \& Parker, M. (2006). Supporting Inclusive Practice: Developing Assessment Toolkit. In M. Adams \& S. Brown (Eds.), Towards Inclusive Learning in Higher Education: Developing Curricula for Disabled (1st Editio, pp. 79-94). New York: Routledge.

Wernsman, M. G. (2008). The Process of Designing and Constructing an Accessible Residence Hall for People with Disabilities on A Public University Campus. Colorado State University.

Zahari, N. F., Harun, S. F., Ahmad, N. A., Zawawi, Z. A., \& Salim, A. N. A. (2016). Comparative Analysis of Disabled Accessibility Needs of Heritage Building in Perak. MATEC Web of Conferences, 66. https://doi.org/10.1051/matecconf/20166600110 